\title{
Morphological and biochemical findings in jejunal biopsies from patients with multiple sclerosis
}

\author{
P. E. J O NES, C. P A L L IS, A N D T . J . P E T ER S \\ From the Department of Medicine, Royal Postgraduate Medical School, London
}

SUMMARY Gluten withdrawal from the diet is occasionally used speculatively in the management of multiple sclerosis. To assess whether there might be any rational basis for such a measure we have undertaken morphological and biochemical studies of the jejunal mucosa in 14 patients with multiple sclerosis. All were found to have morphologically normal villi, and quantitative estimation of surface-to-volume ratios gave values which did not differ from control subjects. Intraepithelial lymphocyte counts were normal. Antigliadin antibody titres were not raised in any patient. Estimation of activity of the brush border disaccharidases (sucrase, lactase, and maltase) showed that the mean level of each enzyme did not differ significantly from control subjects. Analytical subcellular fractionation of the biopsies showed no changes in the distribution or activity of marker enzymes for the brush order, lysosomes, mitochondria, cytosol, peroxisomes, or endoplasmic reticulum. It is concluded that there are no gross morphological or biochemical abnormalities in the jejunal mucosa in patients with multiple sclerosis and, therefore, that the use of gluten-free diets cannot be justified on the assumption that these patients suffer from a coeliac-like lesion of the small intestine.

Epidemiological studies on the prevalence of multiple sclerosis are fraught with difficulties (Acheson, 1977). That environmental factors are involved is now generally accepted (Prineas, 1970) although what these may be is still highly controversial.

It is generally agreed that the prevalence of multiple sclerosis is broadly correlated with latitude, and it may be that within these limits dietary factors are of relevance. It has been argued (Shatin, 1964) that the prevalence is significantly correlated with the geography of cereal cultivation, being high in wheat and rye growing areas, less high in corn (maize) growing regions, and low in the widely separate parts of the world where cassava, millet, and rice provide the main source of dietary protein and carbohydrate.

It is scarcely surprising that in a disease of unknown aetiology, and where little can usually be done for the patients, the latter should tend to clutch at therapeutic straws. In 1973 MacDougall published the results of his personal experience with a gluten-free diet, and his enthusiasm was

Address for reprint requests: Dr C. Pallis, Department of Medicine, Royal Postgraduate Medical School, Hammersmith Hospital, Ducane Road, London W12 OHS.

Accepted 23 October 1978 reported in the media. The medical profession was described at that time as having a closed mind concerning the possible "enteropathic" nature of multiple sclerosis. Matheson (1974) also reported benefit from a gluten-free diet. Neurologists are still asked by patients whether they should go on to such regimens.

A survey of the literature showed that little was known about the intestinal morphology-or the level of antigliadin antibodies-in patients with multiple sclerosis. We, therefore, decided to investigate this aspect of the disease using quantitative methods of assessing possible enterocyte pathology.

\section{Patients and methods}

Between September 1975 and December 1977 we investigated 14 patients admitted or readmitted to the Neurology Unit at Hammersmith Hospital with an unequivocal diagnosis of multiple sclerosis. All fulfilled the diagnostic criteria of Schumacher et al. (1965), and in 12 of the 14 patients IgG accounted for over $12 \%$ of the total CSF protein. There were seven men and seven women, their ages at the time of investigation ranging from 27 to 52 years, and the duration of their illness from 
a few months to over 10 years. No patient had received steroids in the previous three years.

Those participating in the investigation gave informed consent to peroral jejunal biopsy. Severely disabled patients or patients with evidence of organic mental deterioration were excluded from the study. The project was approved by the Research Ethics Committee of the Royal Postgraduate Medical School.

Jejunal biopsies were obtained with the WatsonCrosby capsule under fluoroscopic control $50 \mathrm{~mm}$ distal to the ligament of Treitz; biopsy samples were divided into representative pieces and processed for light microscopy and quantitative morphological assessment, estimation of brush border disaccharidase activities, and analytical subcellular fractionation.

Biopsy specimens were orientated villi uppermost, examined with the dissecting microscope, and fixed in $10 \%$ formalin in normal saline. Vertical sections were cut for histological examination. Surface/volume ratios were determined by the method of Dunnill and Whitehead (1972). and intraepithelial lymphocyte counts quantified by the method of Ferguson and Murray (1971).

Sucrase, lactase, and maltase activities of 11 biopsy samples and analytical subcellular fractionation of specimens from four biopsies were assessed by methods previously described (Peters et al., 1976; Peters, 1976).

Antigliadin antibodies were determined by a modification of the agglutination technique (Boyden, 1951; Gunther et al., 1960).

Patients undergoing jejunal biopsy for investigation of gastrointestinal symptoms and whose biopsy samples were found to be normal on both dissecting microscopy and histological examination served as control subjects.

\section{Results}

\section{MORPHOLOGY}

In all 14 patients dissecting microscopic and histological examination of the jejunal samples showed normal villi. In no patient was subtotal or partial villous atrophy found. Figure 1 shows the surfaceto-volume ratio of the jejunal mucosa from 11 patients with multiple sclerosis and 12 control subjects. There was no significant difference between the multiple sclerosis and control groups. Intraepithelial lymphocytes were counted in 12 biopsies. The mean count was $22 \pm 8$ (SD) per 100 epithelial cells (range 10-34). These values are entirely within the normal range (Ferguson and Murray, 1971).

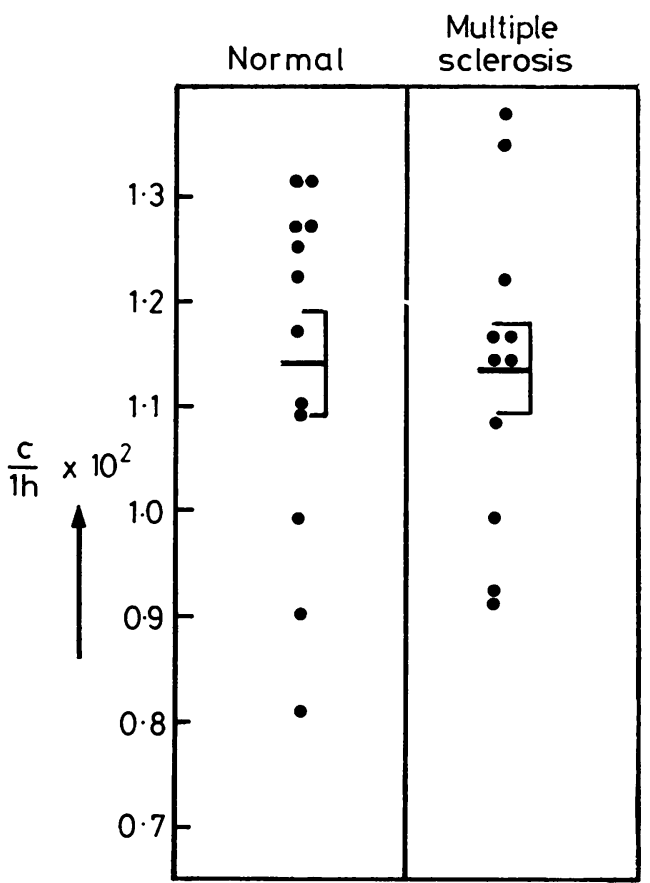

Fig. 1 Surface-to-volume ratios of jejunal biopsies from patients with multiple sclerosis and from control subjects. Bar shows mean $\pm S E M$. Value c/lh defined by Dunnill and Whitehead (1972).

\section{DISACCHARIDASE ACTIVITIES}

Table 1 shows activities of sucrase, lactase, and maltase in 11 multiple sclerosis patients. Two patients showed lactase activity in the range for adult hypolactasia. The mean activities of sucrase, lactase, and maltase did not differ significantly

Table 1 Disaccharidases and antigliadin antibody titres in patients and control subjects

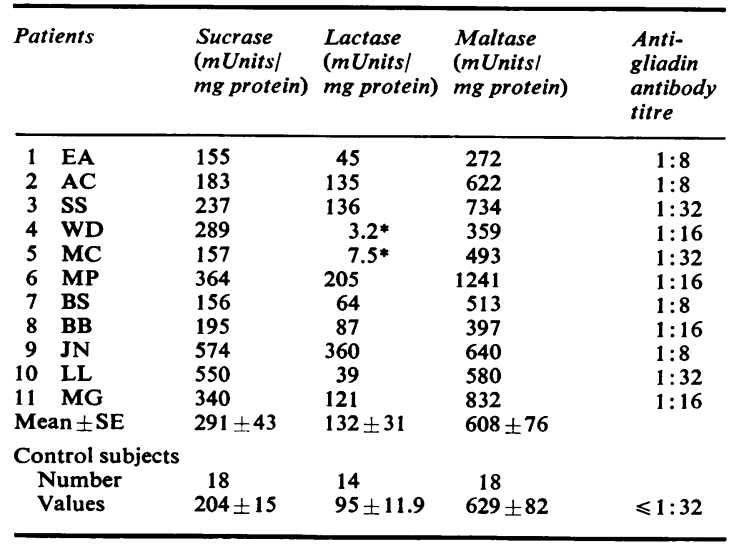

*These patients with hypolactasia omitted from mean lactase result. 
from control subjects (Peters et al., 1976). Table 1 also shows the serum antigliadin antibody titres. In no patient was the value greater than that found in control subjects.

\section{TISSUE ENZYME AND RELEASED ACTIVITY}

Table 2 shows specific activities of certain organelle marker enzymes, estimated in jejunal biopsy homogenates. The percentage activity in the postnuclear supernatant fraction reflects the proportion of cells disrupted and gives a measure of brush border integrity (Peters, 1976). There were no significant differences between the two groups. In particular, there were no alterations in the activities of brush border and lysosomal enzymes, and there was no difference in the percentage of latent $\mathrm{N}$-acetyl- $\beta$-glucosaminidase, a measure of lysosomal integrity (Peters et al., 1975).

Table 2 Enzyme activities in biopsy homogenates from patients and control subjects

\begin{tabular}{|c|c|c|c|}
\hline $\begin{array}{l}\text { Enzyme } \\
\text { (location) }\end{array}$ & Control subjects & $\begin{array}{l}\text { Multiple sclerosis } \\
\text { patients }\end{array}$ & Statistics \\
\hline $\begin{array}{l}\text { Alkaline } \\
\text { phosphatase } \\
\text { (brush border) }\end{array}$ & $\begin{array}{l}64.70 \pm 6.30[15] \\
(36)\end{array}$ & $\begin{array}{l}51.20 \pm 4.60[4] \\
(32)\end{array}$ & $P>0.05$ \\
\hline $\begin{array}{l}\text { Leucyl-2- } \\
\text { naphthylamidase } \\
\text { (brush border) }\end{array}$ & $\begin{array}{l}4.25 \pm 0.78[9] \\
(54)\end{array}$ & $\begin{array}{l}4.64 \pm 0.15[3] \\
(30)\end{array}$ & $P>0.05$ \\
\hline $\begin{array}{l}\gamma \text {-glutamyl } \\
\text { transferase } \\
\text { (brush border) }\end{array}$ & $\begin{array}{l}12.10 \pm 1.40[11] \\
(40)\end{array}$ & $\begin{array}{l}12.50 \pm 1.60[3] \\
(44)\end{array}$ & $P>0.05$ \\
\hline $\begin{array}{l}\mathrm{Zn}^{2+} \text {-resistant } \\
\alpha \text {-glucosidase } \\
\text { (brush border) }\end{array}$ & $\begin{array}{l}8.49 \pm 1.03[8] \\
(36)\end{array}$ & $\begin{array}{l}9.30 \pm 2.40[4] \\
(61)\end{array}$ & $P>0.05$ \\
\hline $\begin{array}{l}\text { Catalase } \\
\text { (peroxisomes) } \\
\text { N-acetyl- } \beta \text { - } \\
\text { glucosaminidase } \\
\text { (lysosomes) }\end{array}$ & $\begin{array}{l}79.90 \pm 5.50[15] \\
(83) \\
6.08 \pm 0.47[14] \\
(56)\end{array}$ & $\begin{array}{l}75.80 \pm 11.70[3] \\
(97) \\
6.14 \pm 0.86[4] \\
(63)\end{array}$ & $\begin{array}{l}P>0.05 \\
P>0.05\end{array}$ \\
\hline $\begin{array}{l}\text { Latent } N \text {-acetyl- } \\
\beta \text {-glucos- } \\
\text { aminidase (\%) }\end{array}$ & $73.60 \pm 1.19[13]$ & $72.50 \pm 2.40[4]$ & $P>0.05$ \\
\hline $\begin{array}{l}\text { Acid phosphatase } \\
\text { (lysosomes) }\end{array}$ & $\begin{array}{l}39.10 \pm 3.80[7] \\
(61)\end{array}$ & $\begin{array}{l}30.90 \pm 4.90[4] \\
(64)\end{array}$ & $P>0.05$ \\
\hline $\begin{array}{l}\text { Acid } \\
\beta \text {-galactosidase } \\
\text { (lysosomes) }\end{array}$ & $\begin{array}{l}1.79 \pm 0.93[4] \\
(72)\end{array}$ & $\begin{array}{l}1.24 \pm 0.23[3] \\
(60)\end{array}$ & $P>0.05$ \\
\hline $\begin{array}{l}\beta \text {-glucuronidase } \\
\text { (lysosomes) }\end{array}$ & $\begin{array}{l}3.05 \pm 0.20[7] \\
(67)\end{array}$ & $\begin{array}{l}3.84 \pm 0.73[3] \\
(69)\end{array}$ & $P>0.05$ \\
\hline $\begin{array}{l}\text { Malate } \\
\text { dehydrogenase } \\
\text { (mitochondria) }\end{array}$ & $\underset{(82)}{3720.00} \pm 310.00[15]$ & $\begin{array}{l}4100.00 \pm 110.00[3] \\
\quad(79)\end{array}$ & $P>0.05$ \\
\hline $\begin{array}{l}\text { Lactate } \\
\text { dehydrogenase } \\
\text { (cytosol) }\end{array}$ & $\begin{array}{l}387.00 \pm 40.00[5] \\
\quad(74)\end{array}$ & $\begin{array}{l}290.00 \pm 86.00[3] \\
\quad(65)\end{array}$ & $P>0.05$ \\
\hline $\begin{array}{l}\text { 5'-Nucleotidase } \\
\text { (basal-lateral } \\
\text { membrane) }\end{array}$ & $\begin{array}{l}41.10 \pm 4.10[8] \\
(50)\end{array}$ & $\begin{array}{l}29.70[1] \\
(52)\end{array}$ & $P>0.05$ \\
\hline Protein & $\begin{array}{l}1.05 \pm 0.14[25] \\
(75)\end{array}$ & $\begin{array}{l}1.82 \pm 0.44[4] \\
(77)\end{array}$ & $P>0.05$ \\
\hline
\end{tabular}

Enzyme activities expressed as mUnits $\pm \mathrm{SE} / \mathrm{mg}$ protein.

Number of specimens analysed shown between square parentheses. Percent activity in post-nuclear supernatant shown between curved parentheses.

Control data taken from Peters (1976) and Peters et al. (1978a).
SUBCELLULAR FRACTIONATION STUDIES

Figure 2 shows a comparison of the density gradient distribution for the marker enzymes for the principal organelles. There are only minor and statistically insignificant differences between patients and control subjects.

\section{Discussion}

None of the 14 multiple sclerosis patients studied was found to have coeliac disease. All had morphologically normal villi (assessed by dissecting and light microscopy), and serum antigliadin antibody titres were all within the normal range. Quantitation of the surface-to-volume ratios showed no significant difference between multiple sclerosis jejunal mucosa and control mucosa. Quantitative counts of intraepithelial lymphocytes, a highly sensitive index of minimal mucosal damage (Ferguson and Murray, 1971; Fry et al., 1972), were entirely normal.

These findings differ from those of Lange and Shiner (1976) who found that one of 12 patients with multiple sclerosis had subtotal villous atrophy, and that another had partial villous atrophy.

Two of 11 of our patients showed hypolactasia. The prevalence of this condition in the Caucasiano population has been estimated at about $10 \%$ (Neale, 1971), and this finding is, therefore, not remarkable. Lange and Shiner (1976) reported shortening of the microvillus membrane on electron microscopy of biopsy samples from multiple sclerosis patients. Our quantitative enzymatic data and subcellular fractionation studies did not indicate any abnormalities in the enterocyte brush borders. The changes in the other organelles were small and probably not significant.

In contrast to these essentially normal findings, patients with coeliac disease show striking enzyme alterations, and the sucrose density gradient experiments demonstrate gross abnormalities in the brush border of the enterocyte (Peters et al., 1978a). This technique of analytical subcellular fractionation with enzymic microanalysis (Peters, 1977) is a highly sensitive technique for demonstrating even minor changes in the intestinal mucosa (Peters et al., 1978b).

We conclude that there are no major morphological or biochemical abnormalities in the intestinal mucosa of patients with multiple sclerosis. The use of gluten-free diets cannot, therefore, be justified on the assumption that these patients suffer from a lesion of the small intestine like that of coeliac disease. 


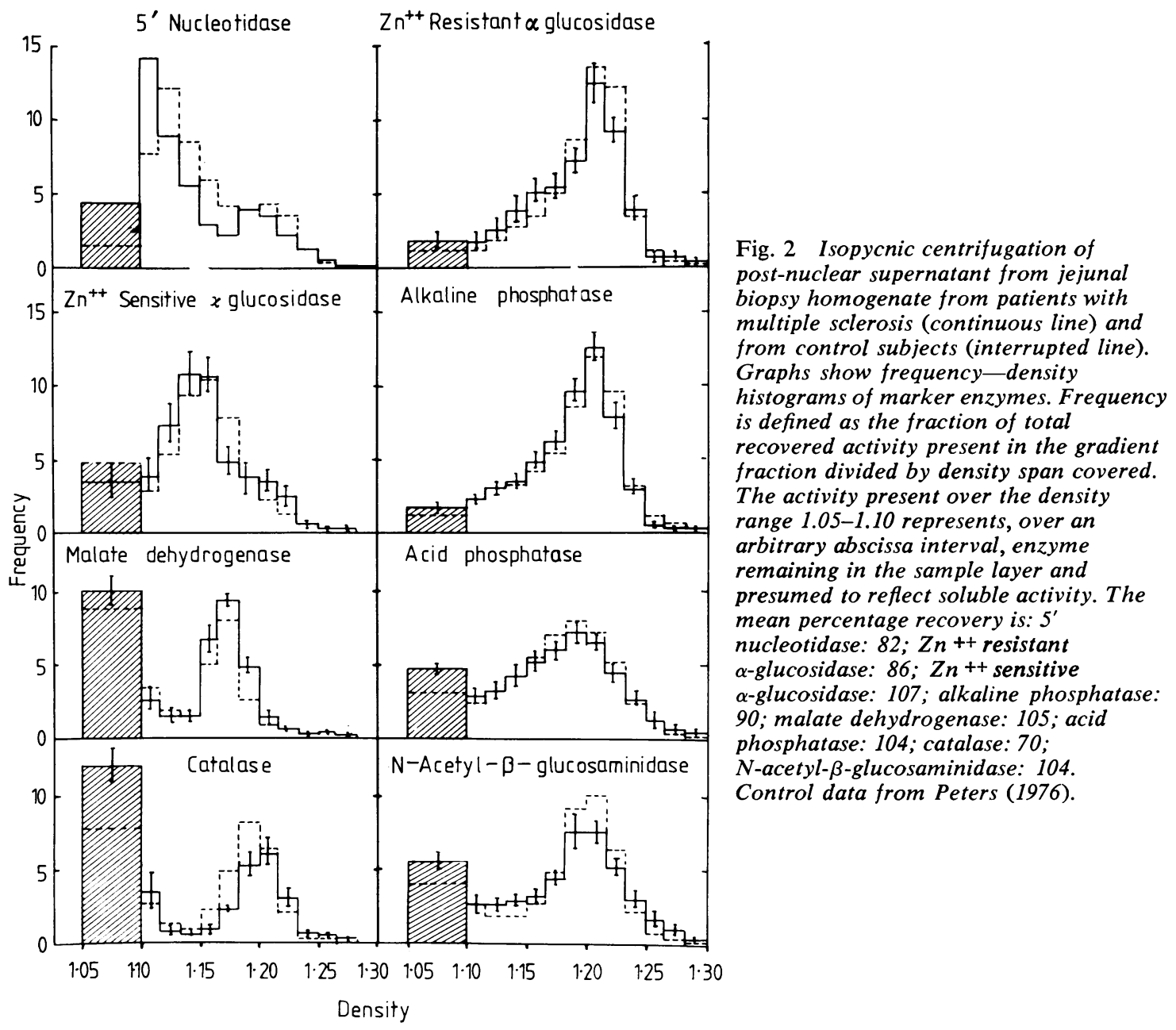

We would like to thank the patients who cooperated in this study, G. Wells, J. Hopkins, and P. White for expert technical assistance, D. R. Pell-Iderton for histological facilities, T. Perry for the illustrations, and J. Gray and C. Chmaj for typing the manuscript. This work was supported in part by the Medical Research Council and the Wellcome Trust.

\section{References}

Acheson, E. D. (1977). Epidemiology of multiple sclerosis. British Medical Bulletin, 33, 9-14.

Boyden, S. V. (1951). The absorption of proteins on erythrocytes treated with tannic acid and subsequent hemagglutination by antiprotein sera. Journal of Experimental Medicine, 93, 107-120.

Dunnill, M. S., and Whitehead, R. (1972). A method for the quantitation of small intestinal biopsy speci- mens. Journal of Clinical Pathology, 25, 243-246.

Ferguson, A., and Murray, D. (1971). Quantitation of intra-epithelial lymphocytes in human jejunum. Gut, 12, 988-994.

Fry, L., Seah, P. P., McMinn, R. M. H., and Hoffbrand, A. V. (1972). Lymphocytic infiltration of epithelium in diagnosis of gluten-sensitive enteropathy. British Medical Journal, 3, 371-374.

Gunther, M., Aschaffenburg, R., Matthews, R. H., Parish, W. E., and Coombs, R. R. A. (1960). The level of antibodies to the proteins of cow's milk in the serum of normal human infants. Immunology, 3, 296-306.

Lange, L. S., and Shiner, M. (1976). Small bowel abnormalities in multiple sclerosis. Lancet, 2, 13191322.

MacDougall, R. (1973). No bed of roses. World Medicine, 8, 98-99.

Matheson, A. (1974). Multiple sclerosis and diet. Lancet, 2, 831. 
Neale, G. (1971). Disaccharidase deficiencies. Journal of Clinical Pathology, 24, Supplement (Royal College of Pathologists), 5, 22-28.

Peters, T. J. (1976). The analytical subcellular fractionation of jejunal biopsy specimens. Methodology and characterisation of the organelles in normal tissues. Clinical Science and Molecular Medicine, 51, 557-574.

Peters, T. J. (1977). Application of analytical subcellular fractionation techniques and tissue enzymic analysis to the study of human pathology. Clinical Science and Molecular Medicine, 53, 503-511.

Peters, T. J., Batt, R. M., Heath, J. R., and Tilleray, J. (1976). The microassay of intestinal disaccharidases. Biochemical Medicine, 15, 145-148.

Peters, T. J., Heath, J. R., Wansbrough-Jones, M. H., and Doe, W. F. (1975). Enzyme activities and properties of lysosomes and brush borders in jejunal biopsies from control subjects and patients with coeliac disease. Clinical Science and Molecular Medicine, 48, 259-267.

Peters, T. J., Jones, P. E., and Wells, G. (1978a). Analytical subcellular fractionation of jejunal biopsy specimens: enzyme activities, organelle pathology and response to gluten withdrawal in patients with coeliac disease. Clinical Science and Molecular Medicine, 55, 285-292.

Peters, T. J., Jones, P. E., Jenkins, W. J., and Nicholson, J. A. (1978b). Analytical subcellular fractionation of jejunal biopsy specimens from control subjects and patients with coeliac disease. In Perspectives in Coeliac Disease, pp. 423-434. Edited by M. McNicholl, C. F. McCarthy, and P. F. Fottrell. MTP Press: Lancaster.

Prineas, J. W. (1970). The aetiology and pathogenesis of multiple sclerosis. In Handbook of Clinical Neurology, volume 9, pp. 107-160. Edited by P. J. Vinken and G. W. Bruyn. North-Holland: Amsterdam.

Schumacher, G. A., Beebe, G., Kibler, R. F., Kurland, L. T., Kurtzke, J. F., McDowell, F., Nagler, B., Sibley, W. A., Tourtellotte, W. W., and Willmon, T. L. (1965). Problems of experimental trials of therapy in multiple sclerosis: report by the panel on the evaluation of experimental trials in multiple sclerosis. Annals of the New York Academy of Sciences, 122, 552-568.

Shatin, R. (1964). Multiple sclerosis and geography: new interpretations of epidemiological observations. Neurology (Minneapolis), 14, 338-344. 